\title{
Sustainable Development: The North-South Relation
}

\author{
M. O. A Ezimah (Ph.D) ${ }^{1 *}$ \\ ${ }^{1}$ Department of Adult and Non-Formal Education, University of Port Harcourt, Nigeria
}

\begin{abstract}
Article History
Received: 07.03.2021

Accepted: 05.04.2021

Published: 24.04.2021

Journal homepage: https://www.easpublisher.com

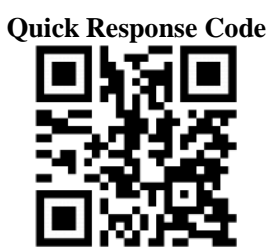

Abstract: The globalization of world economies and the interrelationships with the global environment has given impetus to sustainable development. The overriding importance of this global initiative is to achieve a synergy in local and international policy and legal frameworks which guide development in ways that do not compromise environmental capital for present and future growth. The process leading to this development agenda meant that the countries of the North and South must come to terms with the obvious political, economic and technological landscape that separate them and seek ways to coalesce them. These components of development goals and their overall impact on sustainable development is the focus of this paper.

Keywords: Sustainable development, North-South divide, politics of sustainable development.

Copyright (C) 2021 The Author(s): This is an open-access article distributed under the terms of the Creative Commons Attribution 4.0 International License (CC BY-NC 4.0) which permits unrestricted use, distribution, and reproduction in any medium for non-commercial use provided the original author and source are credited.
\end{abstract}

\section{INTRODUCTION}

Perhaps the most important political conundrum in the world today is the need for a safe environment. The built environment in which humans live and the natural environment in which all settlements are located should be a safe environment. All human progress or lack of it depend, ultimately, on use and misuse of the environment, on healthy or unhealthy environment. The environment has traditionally provided clean water, clean air, and protection against the sun's most harmful rays. It has provided a predictable climate for agriculture, adequate soil and water, and other natural resources. The ways in which human societies have chosen to develop through anti-environmental policies - indicate that the continued supply of these services can no longer be guaranteed.

Timberlake and Thomas [1] observe that it is not just that "the environment" has become more important as a political issue, but that the change has been much more profound. The world has come to the realization that we cannot progress in ways which destroy the environment, as the environment is the basis of all progress. The very nature and meaning of progress have therefore become important political issues.
Consequently, concern for the needs of future generations is beginning to guide policies in the use of resources and the use of the environment. Man is inexorably compelled to live today not only to meet present needs, but so as to leave adequate resources for future generations. Clean air, water, plants, and food supplies are essential for personal health and wellbeing. The relationship between the environment and humanity is one of inter-dependence - each affects the other. Therefore, just as human actions and choices affect the environment, the health of the plant influences personal health and well-being, as well as communities, families, and economies [2].

Today, global environmental problems centre around global warming; ozone depletion and destruction; sharp decrease of forest cover; biological diversity decline; acid rain pollution; land desertification; marine pollution and damage; and water pollution and freshwater resource shortage. These global environmental problems are caused by energy production, deforestation, mining, overpopulation, and increase in global average temperature. Global environmental problems are the result of global environmental change given rise to extreme weather conditions in many parts of the world, threatening the survival of vulnerable species and habitats. All of this affect economic growth. And economic growth caused 
by improved technology can enable higher output with less pollution.

In the light of the above indications, UNEP [3] environment report on, No one safe from global pollution without concerted action, warns as follows:

- UN calls for concerted global action on pollution based on its most comprehensive assessment to date of the links between pollution, health and ecosystems.

- $\quad$ Every part of the plant and every person is affected by pollution, the world's largest killer

- Solutions are within our grasp, but require new policies, enhanced public and private sector leadership at all levels, redirected investments and massive funding.

The UN report contained in a press release indicates that everyone on earth is affected by pollution, and this is based on the analysis of pollution in all its forms, including air, land, fresh water, marine, chemical and waste pollution. The report further adds that without factoring in pollution the world is unlikely to meet the sustainable Development Goals as agreed by all 193 member states in 2015 that guide global development efforts. To achieve these goals, environmental governance is a key enabler. It needs to be multi-stakeholder and multi-level, involving both formal agreements and voluntary initiatives and commitments to achieve success. This is what guarantees environmental standards, health and development for all.

\section{Sustainable Development: The Concept and Issues}

Sustainable development was a key theme of the United Nations Conference on the Human Environment in Stockolm in 1972. The concept was coined explicitly to suggest that it was possible to achieve economic growth and industrialization without environmental damage. The concept, "sustainable development", was founded on three pillars: economic development, social development, and environmental protection $[4,5]$. However, the indigenous peoples had argued for the fourth pillar which is cultural diversity or sustainability.

Satterthwaite et al., [6] admit that there is a considerable confusion as to what is to be sustained by sustainable development. It is also their view that the term "sustainable" is most widely used in reference to ecological sustainability. But during preparations for the Earth Summit held in 1992, and right after, an increasing number of writers and international organizations began to include such concepts as social sustainability, economic sustainability, community sustainability and cultural sustainability as part of sustainable development.

As to what is to be sustained, "social sustainability" when defined as the social conditions necessary to support environmental sustainability are valuable in so far as they stress that natural resources are used within a social context and it is rules and values associated with this context that determine both distribution of resources within the present generation and between the future generations and the present. "Social sustainability" seen in the context of social capital or the social conditions that allow or support the meeting of human needs are also valuable.

Another component of sustainable development is "cultural sustainability". It acquires relevance because of the need within society to develop shared values, perceptions and attitudes indigenous to society and which help to contribute to the achievement of sustainable development. Ecological sustainability becomes a concept for environmental protection interpreted to meet economic, social and political goals for achieving sustainable development since human life and well-being depend on it.

Sustainable development is defined by the Brundtland Report of the World Commission on Environment and Development, WCED [7] thus:

Sustainable development is development that meets the needs of the present without compromising the ability of future generations to meet their own needs. It contains within it two key concepts: the concept of "needs", in particular the essential needs of the world's poor, to which overriding priority should be given; and the idea of limitations imposed by the state of technology and social organization on the environment's ability to meet present and future needs.

The concept of sustainable development appears comprehensive as contained in the original report. But as Rao [8] observes, the definition addresses the issue of intergenerational resources distribution, with expressed concern for the poor. However, it is common that in the on-going debate and discussions, interpretations have centred mainly on intergenerational dimension. Many reports on the theme quote the first sentence leaving the attendant vital explanation and interpretation. This kind of uneven reportage is unfair to the spirit of original contributions, thus given room to unwarranted confusion, and inadequate ventilation of the poverty dimension in literature. The poverty dimension not well examined in the literature adversely affects ecological sustainability and the measure of quality of life - either in the present or in the future.

One of the three conceptual pillars of sustainable development is economic sustainability which implies system of production that satisfies present consumption levels without compromising future needs [5, 9]. Social sustainability encompasses notions of equity, empowerment, accessibility, participation, cultural identity and institutional stability. It implies that people matter since development is about 
people. In a more fundamental sense, social sustainability suggests that a social system that alleviates poverty should neither entail unwarranted environmental destruction nor economic instability. But rather should aim to alleviate poverty within the existing environmental and economic resource base of the society - fostering the development of people, communities and cultures to help achieve meaningful life expressed in proper health care, quality education, gender equality, peace and stability across nations of the North and South [10-13].

Environmental sustainability refers to the natural environment and how it remains productive and resilient to support human life. It relates to ecosystem integrity and caring capacity of natural environment. It entails that natural capital be sustainably used as a source of economic inputs and as a sink for waste. All this implies that natural resources must be harnessed no faster than they can be assimilated by the environment. This is because the earth's systems have limits or boundaries within which equilibrium is maintained [5, 15-17].

Sustainable development is seen as an approach to development which uses resources in ways that allows them to continue to exist for others. It is a principle for meeting human development goals while at the same time sustaining the ability of natural systems to provide the natural resources and ecosystem services upon which the economy and society depend. Sustainable development, therefore, aims to achieve social progress, environmental equilibrium and economic growth. It places emphasis on departure from harmful socio-economic activities to activities with positive environmental, economic and social impacts.

\section{The Politics of Sustainable Development}

The concept of sustainable development is one enmeshed in contradictions and controversies coming from differing economic and political interests - local, national, regional, sub-regional and international planes. Beder [18] sees this as part of a second wave of modern environmentalism that heralds a new approach to tackling environmental problems - a shift from protest to concerns and negotiation. The first wave of environmentalism was associated with the counterculture movement of the 1960s and 1970s. It grew out of traditional nature conservation concerns into an awareness of the potential for a global ecological crisis that was a protest movement.

The second wave of environmentalism started in the late 980s and had received support from a broad spectrum of interests comprising governments, business people and economists in the promotion of sustainable development. This came at a time when there was an incontrovertible evidence that the build-up of greenhouse gases in the atmosphere and the depletion of the ozone layer was a threat to global environment [18].

The concept of sustainable development was reinvented in 1987 when the Brundtland Report of the World Commission on Environment and Development was published. The Commission defined sustainable development as meeting development needs in the "present "and in the "future". Since then other world environmental groups and conservationists such as UNEP, IUCN, WWF/WWFN etc. have emerged to join the campaign to save the world environment. However, there is no gain saying that economic considerations seem to override interest in environmental sustainability - one of the pillars of sustainable development.

The problem of governance for sustainable development has been identified by Dale [19] as that inherited from the nineteenth century which is a model structured around functions and services, rather than around solving problems. Ann Dale proffers that only when governments organize dynamically around the problem and respond to the modern context that they become more relevant to citizens and contribute to a more robust civil society. She therefore identifies the following characteristic of sustainable development problems as they:

- $\quad$ are more complex and interactive than is generally assumed;

- are ones that emerge in several places and suddenly, for example, the hole in the ozone layer, rather than ones that emerge only locally at a speed that is rapid enough to be noticed;

- move both human and natural systems into such novel and unfamiliar territory that aspects of the future are not only uncertain, but are inherently unpredictable;

- $\quad$ are ones where knowledge, therefore, will always be uncertain and information incomplete;

- transcend man-made political boundaries;

- $\quad$ - are scale place and time dependent, and must be defined according to the type, intensity and frequency of use;

- $\quad$ are interdependent and holistic; and

- have highly diffused contexts, involving a multiplicity of actors.

According to Dale [19] sustainable development issues therefore:

(a) have multiple contexts;

(b) involve multiple and often diametrically opposed values;

(c) demand an unprecedented interface between academic research and public policy; and

(d) there is no such thing as sustainable development expertise, but rather, a multiplicity of exercise. 
To respond to sustainable development imperatives, Ann Dale recommends:

(a) multiple ways of organizing around specific issues, depending upon context,

(b) multiple tools,

(c) multiple research methodologies, and most importantly,

(d) interdisplinary networks of collaboration.

To remedy sustainable development problems, therefore, will require the adoption of ad hoc rather than 'larger than life' structures which are fraught with bottlenecks. When sustainable development issues are identified, they should be discussed along vertical rather than horizontal lines since these issues are broad and cut across all sectors of society. At the moment issues are addressed as a matter of government business, with stakeholders having diverse and contending interests especially that between North-South divide.

Understandably, the vision of sustainable development has the potential to unite many pressure groups under one common banner. It is a concept that unites environmentalists and those concerned with progress in the South with a message that there can be no progress in a ravaged environment, and that progress based on short-sighted goals can only ravage the environment.

One of such groups Oxfam, a development group, according to Timberlake and Thomas [1], campaigns on environmental issues across Africa because they cannot improve their economic lot in a bankrupt environment. A similar group the World Wide Fund for Nature (WWF), traditionally a species protection organization, has expanded its scope to include development issues such as the debt crisis, because heavily indebted nations are forced to destroy forests and other natural habitats of species for money making venture

Timberlake and Thomas maintain that sustainable development is a "women's rights" "issue, not only because women are the direct caretakers of the environment, as they do so much of the farming, wood collecting and water hauling in the Third World, but because effective citizens' participation in decision making requires the effective participation of women. Effective participation would also require the involvement of minority groups such as indigenous peoples, especially those living in the rainforests and other fragile ecosystems. It would also include peace groups because SD demands a redefinition of "security" based on ecological security, which cannot be attained with weapons. This approach to sustainable development would embrace information campaigners, who are concerned with access to environmental information.
By and large, a sustainable world progress will require levels of international cooperation in which groups concerned with promoting teamwork - such as the United Nations Associations - are engaged in their support. This united concern and action is not a theoretical ideal, but real, snowballing into world event made up of conservationists and environmental groups making more visible presence in the UK and US.

\section{The North-South Divide}

The 17 Goals for Sustainable Development of the United Nations [21] has the following preamble: The 2030 Agenda for Sustainable Development, adopted all United Nations Member States in 2015, provides a shared blueprint for peace and prosperity for people and the planet, now and into the future. At its heart are the 17 Sustainable Development Goals (SDGs), which are an urgent call for action by all countries - developed and developing - in a global partnership. They recognize that ending poverty and other deprivations must go hand-in-hand with strategies that improve health and education, reduce inequality, and spur economic growth - all while tackling climate change and working to preserve our oceans and forests.

A look at the above preamble and the 17 SDGs will indicate that all are tied to tackling climate change and preservation of the environment. Therefore, a 7 summary objectives of the 17 SDGs will suffice in this section thus:

- Eradicate poverty and hunger, guaranteeing a healthy life

- Universalize access to basic services such as water, sanitation and sustainable energy

- Support the generation of development opportunities through inclusive education and decent work

- Foster innovation and resilient infrastructure, creating communities and cities able to produce and consume sustainably

- Reduce inequality in the world especially that concerning gender

- Care for the environmental integrity through combatting climate change and protecting the oceans and land ecosystems

- Promote collaboration between different social agents to create an environment of peace and ensure responsible consumption and production.

The North and South are sharply divided on account of climate change. For many decades, the North has used its technological pre-eminence to impoverish the South. But the sad reality which is a reason for the disadvantaged position of the South is that the latter had suffered colonialism and neo-colonialism. 
Gonzalez [20] acknowledges this historical antecedent as she chronicles that the origins of the North-South divide lie in colonialism. A picturesque description is provided in this lucid narrative:

The colonial encounter devastated the indigenous civilizations of Asia, Africa, and the Americas, and enabled Europeans to appropriate and exploit their lands, labor, and natural resources. Colonialism converted self-reliant economies into outposts of Europe that exported agricultural products minerals, and timber, and imported manufactured goods. Mining, logging, and cash-crop destroyed forests, dispossessed local communities, and dramatically altered the ecosystems of the colonized territories.

Consequently, this historical tragedy has created a global economy that systematically subordinated the global South. The post-colonial states in Asia, Africa and Latin America were integrated into the Northern-dominated world economy as exporters of primary commodities and importers of manufactured products. As a result, the terms of trade consistently favoured manufactured goods over primary products and the nations of the global South were required to export large amounts of their output in order to acquire the same amount of manufactured goods. Efforts to boost national earnings by increasing the production of minerals, timber, and agricultural products led to a glut in global markets with primary commodities and depressed prices, thereby reducing Southern export earnings, exacerbating Southern poverty, and reinforcing the North-South environmental and economic divide.

The economic dependency of the South on export production enabled the North to exploit Southern resources at prices that did not reflect the social and environmental costs of production. Far from producing prosperity, export-led development strategies depleted natural resources of the South, harmed human health, and reinforced social and economic inequality by imposing disparate environmental burdens on the communities targeted for petroleum extraction, mining, and other forms of resource exploitation.

This trajectory of history has created immense ecological crisis, solution to which demands that the North pay reparation to the South for the environmental and economic woes - an act of savagery inflicted on them. This is one sure approach of giving sustainable development a meaning to the people of the South. As Carmen Gonzalez documents that the international economic order is conditioned by unlimited economic growth that impoverishes the global South and facilitates the overconsumption of the planet's resources by affluent inhabitants of the planet. It is an undeniable statement that unbridled pursuit of economic growth has brought the planet's ecosystems to the brink of collapse. The United Nations Millennium Ecosystem
Assessment Synthesis Report of 2005 concluded that human economic activity in the last fifty years has produced more severe degradation of the planet's ecosystems than at any other period in human history.

The North reaps the material benefits of economic expansion while the environmental consequences are borne disproportionately by people in the South and by the most vulnerable human beings, including indigenous peoples, racial and ethnic minorities, and the poor. The North has achieved industrialization at the expense of the South by appropriating its natural resources. It is for this reason that is argued that the North owes an ecological debt to the South for resource plundering, unfair trade, environmental damage, and the dumping of waste in its environment. This environmental rape and debt are at the heart of many North-South conflicts in international environmental fora and environmental law.

In an article on North-South Divide is marring environment talks published on New York Times, Simons [22] reveals the breadth of the divide. In preparation for the United Nations Conference on Environment and Development in Rio de Janeiro, a United Nations official who attended most of the planning sessions said much of the debate was confrontational, characterizing the message from developing countries as "give us money; you are rich; we are poor". An official from a Caribean nation said: "for the first time in more than a decade, the developing countries have an issue where they have some real leverage.

They had none during the debt negotiations. But they are part of the environment, so they have leverage now. And they are using it. It's their negotiating strategy.

The poor nations, he, said, see leverage because the North, the main polluter, wants them to cut emissions, stop deforestation and make other changes. But to adapt to those changes, they argue, they need funding and technology. The confrontation that was part of preparation for the summit meeting since the United Nations resolution in 1989 calling for it attributing the planet's environmental problems "unsustainable production patterns" of the industrial countries, still persist. As Marlise Simons put it, "most proposals for action demand enormous transfers of money and technology from the industrial world to the developing world that would put almost all responsibility on the rich countries.

The demand by the South to "Give us money" approximates to the demand for reparation. Nearly three decades after the Earth Summit, the conditions for which the demands are made have not changed. And the 
dividing line between the North and South get wider and wider with the passage of time.

\section{CONCLUSION}

The dividing line between the North and South is centred on environment and trade policy but shrouded in politics. The richer countries are unwilling to take responsibility for the new world economic order they created, and to make the necessary adaptation and pay for a change. The initial impetus in the North to give aid to the South came from a vague sense of clarity, coupled with a desire to buy up Southern allies in the cold war. Then the Brandt Commission reports of the early 1980s argued that not only did the North have a moral imperative to aid Southern development, but such development would create more markets for Northern goods and more security for Northern peoples. Neither the moral nor the mutual benefits argument has had the desired effect. The world remains at a tuning-point so long as global environmental issues continue to beg the question.

\section{REFERENCES}

1. Timberlake, L., \& Thomas, L. (1990). When the bough breaks: Our children, our environment. London: Earthscan publications Ltd.

2. University of Minnesota. (2016). Why is global environmental health important? Taking charge of your health and wellbeing. www.takingcharge.csh.umn.edu>why-globaleniron...

3. UNEP. (2017). No one safe from global pollution without concertion action. A press release. www.unenvironment.org> press-release >no-onesafe...

4. Social Watch. (2011). What is sustainable Development? The evolution of the idea. www.socialwtach .org>node

5. Mensah, J. (2019). Sustainable Development: Meaning, history, principles, pillars, and implications for human action: Literature Review. www.tandfonline.com $>$ doi $>$ abs

6. Satterthwaite, D. (1996). The Environment for Children: Understanding and acting on the environmental hazards that threaten children and their parents. Earthscan.

7. WCED, S. W. S. (1987). World commission on environment and development. Our common future, 17(1), 1-91.

8. Rao, P. K. (2000). Sustainable development: Economics and policy. Oxford: Blackwell Publishers.

9. Lobo, M. J., Pietriga, E., \& Appert, C. (2015, April). An evaluation of interactive map comparison techniques. In Proceedings of the 33rd annual ACM conference on human factors in computing systems (pp. 3573-3582).

10. Saith, A. (2006). From universal values to millennium development goals: Lost in translation. Development and change, 37(6), 1167 1199.

11. Daly, K. (1992). Women's pathways to felony court: Feminist theories of lawbreaking and problems of representation. S. Cal. Rev. L. \& Women's Stud., 2, 11.

12. Hajirasouli, A., \& Kumarasuriyar, A. (2016). The social dimention of sustainability: Towards some definitions and analysis. Journal of Social Science for Policy Implications, 4(2), 23-34.

13. Benaim, A., Collins, A., \& Raftis, L. (2008). Social dimension of sustainable development: guidance and application.

14. Diesendorf, M. (2000). Sustainability and sustainable development. Sustainability: The corporate challenge of the 21 st century, 2, 19-37.

15. Evers, A. W., Colloca, L., Blease, C., Annoni, M., Atlas, L. Y., Benedetti, F., ... \& Kelley, J. M. (2018). Implications of placebo and nocebo effects for clinical practice: expert consensus. Psychotherapy and psychosomatics, 87(4), 204-210.

16. Goodland, R., \& Daly, H. (1996). Environmental sustainability: universal and nonnegotiable. Ecological applications, 6(4), $1002-$ 1017.

17. Brodhag, C., \& Talière, S. (2006, May). Sustainable development strategies: Tools for policy coherence. In Natural Resources Forum (Vol. 30, No. 2, pp. 136-145). Oxford, UK: Blackwell Publishing Ltd.

18. Beder, B. (1994). Revolting developments: The politics of sustainable development. Politics of sustainable development-UOW. www.uow.edu.au>sharonb $>$ esd $>$ arena

19. Dale, A. (n.d.). The politics of sustainable development. Encyclopedia of Life Support Systems. www.eolss.netssample-chapters.

20. Gonzalez, C. (2015). Bridging the North-South divide: International environmental law in the anthropogenic.

Digitalcommons.law.seattleu.edu $>$ cgi $>$ viewcontent

21. United Nations. (2015). Sustainable dent Goals. Department of Economic and Social Affairs. Sdgs.un.org>goals.

22. Simons, M. (1992). North-South divide is marring environment talks. The New York Times. www.nytimes.com>1992/03/17> world>northsouth-di...

Cite This Article: M. O. A Ezimah (2021). Sustainable Development: The North-South Relation. East African Scholars J Edu Humanit Lit, 4(4), 196-201. 